\title{
The Correlation Between Head and Face, and Dental Arch of Children with Congenital Rubella Syndrome
}

\author{
Moriyoshi Murakami, Atsushi Rokutanda and Rei Ito \\ Department of Anatomy (Chief : Prof. Hiroshi Yamada) \\ Tomio Iha, Akira Yuda and Eiichi Saeki \\ Department of Preventive Dentistry (Chief : Prof. Eiichi Saeki) \\ Kyushu Dental College, Kitakyushu, Japan \\ Received December 1st, 1978.
}

\section{Indroduction}

Between the latter half of 1964 and the first half of 1965 rubella was found in epidemic proportions in Okinawa. It affected pregnant mothers who gave birth to children with defected hearts, eyes, hearing, insufficient body weight at birth, bone growth, central nervous system, microcephalia, micrognathia, etc.. Since then, the actual conditions of the congenital rubella syndrome in Okinawa have been investigated by many investigator. However, there is no detailed report on the microcephalia and micrognathia, which are defects involved in the congenital rubella syndrome.

The authors reported in previous research on the somatological measurement of the head and face of children, aged 12 years old, with congenital rubella syndrome. The conclusion of the above report was that the children with congenital rubella syndrome were smaller than the normal control children with statistical significance, especially in terms of bracycephalic type, europrosopic type, and remarkable narrow bigonial breadth.

In this paper, we report the correlation between the above somatological measurements and dental arch (including palatal vault height).

\section{Materials and Methods}

The somatological measurement of the head and face, and the impression taking of the upper and lower dental arches were done on the children affected with congenital rubella syndrome (male 53, female 49 and total 102), in August, 1977. These children were born between February, 1965 and January, 1966. They attend a special class for those with hearing handicaps due to rubella. This class is located in the middle south part of Okinawa.

Measurements of the head and face include head length, head breadth, bizygomatic breadth and morphological face height. Bigonial breath is measured according to the 
agreement of the somotological measuring team of the Japan Science Council, and other measurements to Martin-Saller (1956) ${ }^{1}$.

Measurements of the dental arch include the length and breadth of upper and lower dental arches and palatal vault height.

The control group is composed of school children attending an elementary school in Naha city, who are the same age as the children with congenital rubella syndrome. The control group includes 35 males, 34 females and totals 69 . Somatological measurement of the head and face was conducted on these children, and the impression taking of upper and lower dental arches was done as well. These measurements were used in the present report. Measurements of dental arch and palatal vault height were done on the plaster model taken with alginate impression material. The landmarks of dental arches for measurement are shown on Fig. 1; A--contact point between upper centrals, B--mesiobuccal pits of upper right and left first molars, C--contact points on the distal of upper right and left first molars, $A^{\prime}$-- contact point between lower centrals, $B^{\prime}$--central fossae of lower right and left first molars, C'--contact points on the distal of lower first molars. For the accuracy of measurement, no teeth with fillings and crown restorations was involved. Occlusal plane was used as the standard plane for measurement.

1) Upper dental arch length; distance between $A$ and $M$ which is the middle of upper right and left $\mathrm{C}$ points (distance $\mathrm{A}-\mathrm{M})$.

2) Upper dental arch breadth; sum of the perpendiculars from right and left $B$ points to $A-M$ line $\left(B P+B P^{\prime}\right)$.

3 ) Lower dental arch length; distance
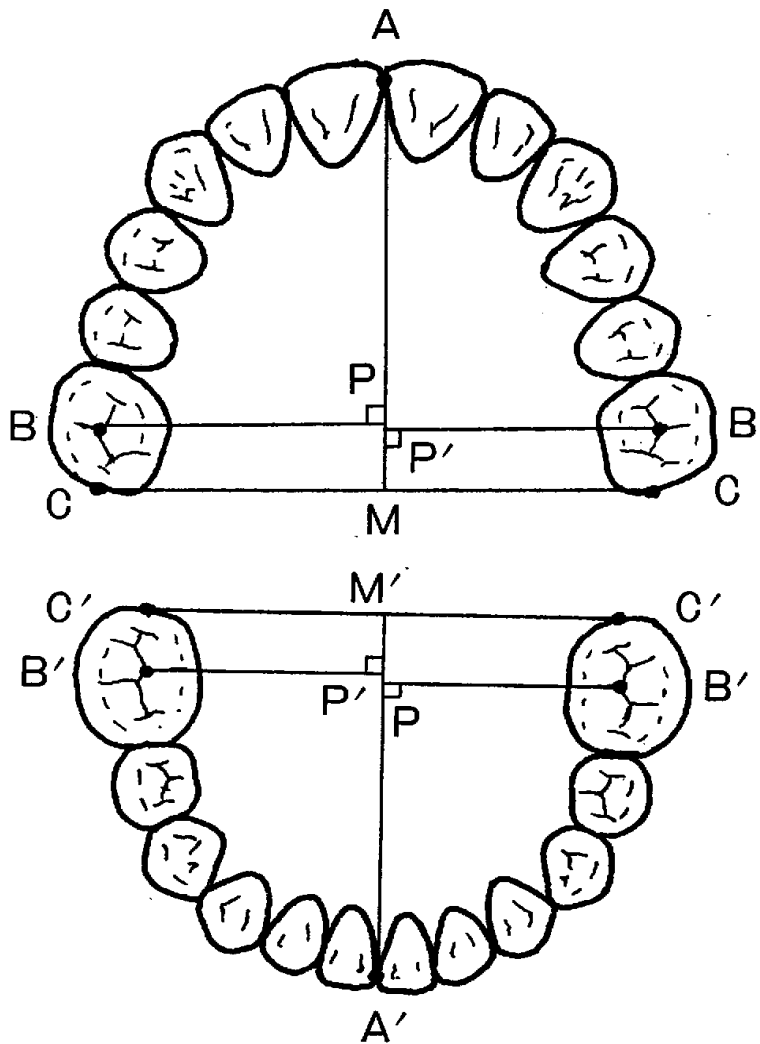

Fig. 1 Point fo mesurements between $A^{\prime}$ and $M^{\prime}$ which is the middle of lower right and left $C^{\prime}$ points (distance $\left.A^{\prime}-M^{\prime}\right)$.

4) Lower dental arch breadth; sum of the perpendiculars from right and left $B^{\prime}$ points to $A^{\prime}-M^{\prime}$ line $\left(B^{\prime} P+B^{\prime} P^{\prime}\right)$.

5 ) Palatal vault height; distance between palate and the middle of right and left $B$ points, and this line is perpendicular to the occlusal plane.

Using MITSUTOYO contracer, curvature of the palatal vault, which is on the plane 
connecting right and left B points and perpendicular to the occlusal plane, was converted into ground plane. On this ground plane, measurement was done with a scale with $1 / 20 \mathrm{~mm}$ sub-scale.

Due to the improper plaster models of the control group, the correct measurement of the palatal vault height of this group was not attained and it is eliminated on this report.

D. $\geqq 2$ diff. was regarded to be of significance in the comparison of the values.

\section{Results}

I . The dental measuremants

The measurements of dental arches and palatal vault height of children with Congenital Rubella Syndrome (CRS) and the control group are shown on the Table 1.

1. Upper dental arch length

CRS : The average upper dental arch length for the male is $37.09 \mathrm{~mm}$, and $35.85 \mathrm{~mm}$ for the female. There is a significant sex difference and the male showed larger measurements.

Control: The average upper dental arch length for the male is $37.72 \mathrm{~mm}$, and $36.70 \mathrm{~mm}$ for the female. There is no significant sex difference.

The children with CRS showed smaller measurements than the control group, but there is no significant difference.

2. Upper dental arch breadth

CRS : The average upper dental arch breadth for the male is $47.87 \mathrm{~mm}$, and $45.98 \mathrm{~mm}$ for the female. There is a significant sex difference and the male showed larger measurements.

Table 1. Measurements of dental arch with congenital rubella syndrome (CRS) and control group

\begin{tabular}{|c|c|c|c|c|c|c|c|c|c|c|c|}
\hline & \multicolumn{4}{|c|}{ CRS } & \multicolumn{4}{|c|}{ Control } & \multicolumn{2}{|c|}{ CRS-control } \\
\hline & & \multirow[b]{2}{*}{$\mathrm{n}$} & \multicolumn{3}{|c|}{$\hat{o}-q$} & \multirow[b]{2}{*}{$n$} & \multicolumn{3}{|c|}{ s - 우 } & & \\
\hline & & & $\mathrm{M} \pm \mathrm{m}$ & D. \pm m.diff. & $\mathrm{D} / \mathrm{m}$ & & $\mathrm{M} \pm \mathrm{m} \quad \mathrm{D}$ & m.diff. & $\mathrm{D} / \mathrm{m}$ & D. \pm & $\mathrm{D} / \mathrm{m}$ \\
\hline Jpper & $\hat{o}$ & 50 & $37.09 \pm 0.36$ & & & 19 & $37.72 \pm 0.51$ & & & -0 & 1.02 \\
\hline rch length & q & 45 & $35.85 \pm 0.39$ & & & 21 & $36.70 \pm 0.57$ & & & -0 & 1.2 \\
\hline Upper dental & $\$$ & 49 & $47.87 \pm 0.36$ & & & 20 & $49.52 \pm 0.47$ & & & $-1.65 \pm 0.59$ & 2.8 \\
\hline breadth & 우 & 45 & $45.98 \pm 0.42$ & & 4 & 22 & $47.42 \pm 0.48$ & & 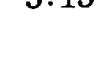 & -1 & 2.2 \\
\hline alatal vault & $\hat{0}$ & 41 & $13.83 \pm 0.31$ & & 0.0 & & & & & & \\
\hline gth & 9 & 34 & $13.87 \pm 0.32$ & & & & & & & & \\
\hline Lower dental & $\uparrow$ & 45 & $33.71 \pm 0.40$ & .54 & 3.76 & 16 & $33.98 \pm 0.54$ & \pm 0.77 & 2.34 & $-0.27 \pm 0.67$ & 0.40 \\
\hline arch length & q & 41 & $31.68 \pm 0.37$ & $00-0.04$ & & 20 & $32.18 \pm 0.55$ & & & $-0.50 \pm 0.66$ & 0.7 \\
\hline Lower dental & $\hat{o}$ & 43 & $42.64 \pm 0.38$ & & 3.74 & 18 & $44.61 \pm 0.49$ & $2.22 \pm 0.69$ & 3.22 & $-1.97 \pm 0.62$ & 3.1 \\
\hline rch breadth & 우 & 42 & $40.62 \pm 0.39$ & $U Z I$ & 3.14 & 21 & $42.39 \pm 0.48$ & $2.22 \pm 0.09$ & 3.24 & $-1.77 \pm 0.62$ & 2.85 \\
\hline
\end{tabular}




\section{Correlation between Head and Face, and Dental Arch of Children} with CRS (Murakami, et al.)

Control: The average upper dental arch breadth for the male is $49.52 \mathrm{~mm}$, and $47.42 \mathrm{~mm}$ for the female. There is a significant sex difference and the male showed larger measurements.

The CRS group showed smaller measurements than the control group and the difference is significant.

3. Palatal vault height

CRS : The average palatal vault height for the male is $13.83 \mathrm{~mm}$, and $13.87 \mathrm{~mm}$ for the female. There is no significant sex difference.

4. Lower dental arch length

CRS: The average lower dental arch length for the male is $33.71 \mathrm{~mm}$, and $31.68 \mathrm{~mm}$ for the female. There is a significant sex difference and the male showed larger measurements.

Control: The average lower dental arch length for the male is $33.98 \mathrm{~mm}$, and $32.18 \mathrm{~mm}$ for the female. There is a significant sex difference and the male showed larger measurements.

Though the CRS group showed smaller measurements than the control group, there is no significant difference.

5. Lower dental arch breadth

CRS : The average lower dental arch breadth for the male is $42.64 \mathrm{~mm}$, and $40.62 \mathrm{~mm}$ for the female. There is a significant sex difference and the male showed larger measurements than did the female.

Control: The average lower dental arch breadth for the male is $44.61 \mathrm{~mm}$, and $42.39 \mathrm{~mm}$ for the female. There is a significant sex difference and the male showed larger measurements than did the female.

The male and female with CRS group showed smaller measurements than the control group, and the difference is significant.

II . The correlation between head and face, dental arch and palatal vault height.

As for the correlation, results will be reported only for the CRS group because correct coefficient of correlation was not attained due to insufficient correspondence between the measured values of head and face, and plaster models of dental arches of the control group.

The coefficients of correlation for five items of head and face measurements and five items of dental arch measurements of the CRS group are shown on the Tables $2 \sim 4$.

1. The correlation between lengths .

Head length and upper dental arch length: There is no significant correlation in terms of the males, the females and the total of males and females.

Head length and lower dental arch length : There is a significant positive correlation in terms of the females and the total of males and females.

2 . The correlation between breadths.

Head breadth and upper dental arch breath : There is a significant positive correlation 
in terms of the females and the total of males and females.

Bizygomatic breadth and upper dental arch breadth: There is a significant positive correlation in terms of the males, the females and the total of males and females.

Bizygomatic breadth and lower dental arch breadth: There is a significant positive correlation in terms of the females and the total of males and females.

Table 2. Coefficient of correlations between measurements of head and face, and measurements of dental arch with CRS ( $\hat{o})$

\begin{tabular}{|c|c|c|c|c|c|c|c|c|c|c|c|c|c|c|c|}
\hline & \multicolumn{3}{|c|}{ Head length } & \multicolumn{3}{|c|}{ Head breadth } & \multicolumn{3}{|c|}{$\begin{array}{l}\text { Bizygomatic } \\
\text { breadth }\end{array}$} & \multirow[b]{2}{*}{$\mathrm{n}$} & \multicolumn{2}{|c|}{$\begin{array}{l}\text { Bigonial } \\
\text { breadth }\end{array}$} & \multicolumn{3}{|c|}{$\begin{array}{l}\text { Morphological } \\
\text { face height }\end{array}$} \\
\hline & $\mathrm{n}$ & $\mathbf{r}$ & ts & $\mathrm{n}$ & r & ts & $\mathrm{n}$ & $\mathbf{r}$ & ts & & $r$ & ts & $\mathbf{n}$ & $\mathbf{r}$ & ts \\
\hline $\begin{array}{l}\text { Upper dental } \\
\text { arch length }\end{array}$ & 50 & 0.14 & 0.98 & 50 & 0.08 & -0.56 & 50 & 0.11 & 0.77 & 50 & 0.13 & 0.91 & 50 & 0.26 & 1.87 \\
\hline $\begin{array}{l}\text { Upper dental } \\
\text { arch breadth }\end{array}$ & 49 & 0.18 & 1.25 & 49 & 0.27 & 1.92 & 49 & 0.46 & $3.55^{*}$ & 49 & 0.57 & $4.76^{*}$ & 49 & 0.11 & 0.76 \\
\hline $\begin{array}{l}\text { Palatal vault } \\
\text { height }\end{array}$ & 41 & 0.11 & 0.69 & 41 & 0.04 & 0.25 & 41 & -0.18 & -1.14 & 41 & 0.02 & 0.12 & 41 & 0.45 & $3.15^{*}$ \\
\hline $\begin{array}{l}\text { Lower dental } \\
\text { arch length }\end{array}$ & 45 & 0.18 & 1.20 & 45 & 0.10 & 0.66 & 45 & 0.20 & 1.34 & 45 & 0.21 & 1.41 & 45 & -0.01 & -0.07 \\
\hline $\begin{array}{l}\text { Lower dental } \\
\text { arch breadth }\end{array}$ & 43 & 0.11 & 0.71 & 43 & 0.26 & 1.72 & 43 & 0.25 & 1.65 & 43 & 0.39 & $2.71^{*}$ & 43 & 0.14 & 0.91 \\
\hline
\end{tabular}

* : Significant at the $5 \%$ level confidence

Table 3. Coefficient of correlations between measurements of head and face, and measurements of dental arch with CRS (ㅇ)

\begin{tabular}{|c|c|c|c|c|c|c|c|c|c|c|c|c|c|c|c|}
\hline & \multicolumn{3}{|c|}{ Head length } & \multicolumn{3}{|c|}{ Head breadth } & \multicolumn{3}{|c|}{$\begin{array}{l}\text { Bizygomatic } \\
\text { breadth }\end{array}$} & \multirow[b]{2}{*}{$\mathrm{n}$} & \multicolumn{2}{|c|}{$\begin{array}{l}\text { Bigonial } \\
\text { breadth }\end{array}$} & \multicolumn{3}{|c|}{$\begin{array}{l}\text { Morphological } \\
\text { face height }\end{array}$} \\
\hline & $\mathrm{n}$ & $\mathbf{r}$ & ts & $\mathrm{n}$ & $\mathbf{r}$ & ts & $\mathrm{n}$ & $\mathbf{r}$ & ts & & $\mathbf{r}$ & ts & $\mathbf{n}$ & $\mathbf{r}$ & ts \\
\hline $\begin{array}{l}\text { Upper dental } \\
\text { arch length }\end{array}$ & 45 & 0.27 & 1.84 & 45 & 0.20 & 1.34 & 45 & 0.15 & 0.99 & 45 & 0.23 & 1.55 & 45 & 0.35 & $2.45^{*}$ \\
\hline $\begin{array}{l}\text { Upper dental } \\
\text { arch breadth }\end{array}$ & 45 & 0.28 & 1.91 & 45 & 0.36 & $2.53^{*}$ & 45 & 0.59 & $4.79^{*}$ & 45 & 0.42 & $3.03^{*}$ & 45 & 0.34 & $2.37^{*}$ \\
\hline $\begin{array}{l}\text { Palatal vault } \\
\text { height }\end{array}$ & 34 & 0.32 & 1.91 & 34 & -0.15 & -0.86 & 34 & 0.11 & 0.63 & 34 & 0.14 & 0.80 & 34 & 0.16 & 0.92 \\
\hline $\begin{array}{l}\text { Lower dental } \\
\text { arch length }\end{array}$ & 41 & 0.33 & $2.18^{*}$ & 41 & 0.15 & 0.95 & 41 & 0.08 & 0.50 & 41 & 0.02 & 0.12 & 41 & 0.02 & 0.12 \\
\hline $\begin{array}{l}\text { Lower dental } \\
\text { arch breadth }\end{array}$ & 43 & 0.20 & 1.31 & 43 & 0.33 & $2.24^{*}$ & 43 & 0.43 & $3.05^{*}$ & 43 & 0.33 & $2.24^{*}$ & 43 & 0.22 & 1.44 \\
\hline
\end{tabular}

* : Significant at the $5 \%$ level confidence 
Table 4. Coefficient of correlations between measurements of head and face, and measurements of dental arch with CRS ( $\hat{\delta}+q)$

\begin{tabular}{lcccccccccccccccccc}
\hline & \multicolumn{1}{c}{ Head length } & \multicolumn{4}{c}{ Head breadth } & \multicolumn{3}{c}{$\begin{array}{c}\text { Bizygomatic } \\
\text { breadth }\end{array}$} & \multicolumn{4}{c}{$\begin{array}{c}\text { Bigonial } \\
\text { breadth }\end{array}$} & \multicolumn{3}{c}{$\begin{array}{c}\text { Morphological } \\
\text { face height }\end{array}$} \\
& $\mathrm{n}$ & $\mathrm{r}$ & $\mathrm{ts}$ & $\mathrm{n}$ & $\mathrm{r}$ & $\mathrm{ts}$ & $\mathrm{n}$ & $\mathrm{r}$ & $\mathrm{ts}$ & $\mathrm{n}$ & $\mathrm{r}$ & $\mathrm{ts}$ & $\mathrm{n}$ & $\mathrm{r}$ & $\mathrm{ts}$ \\
\hline $\begin{array}{l}\text { Upper dental } \\
\text { arch length }\end{array}$ & 95 & 0.18 & 1.76 & 95 & 0.34 & $3.49^{*}$ & 95 & 0.18 & 1.76 & 95 & 0.22 & $2.17^{*}$ & 95 & 0.38 & $3.96^{*}$ \\
$\begin{array}{l}\text { Upper dental } \\
\text { arch breadth }\end{array}$ & 94 & 0.24 & $2.37^{*}$ & 94 & 0.40 & $4.19^{*}$ & 94 & 0.56 & $6.48^{*}$ & 94 & 0.51 & $5.69^{*}$ & 94 & 0.30 & $3.02^{*}$ \\
$\begin{array}{l}\text { Palatal vault } \\
\text { heigth }\end{array}$ & 75 & 0.26 & $2.30^{*}$ & 75 & -0.04 & -0.34 & 75 & -0.08 & -0.69 & 75 & 0.11 & 0.95 & 75 & 0.30 & $2.69^{*}$ \\
$\begin{array}{l}\text { Lower dental } \\
\text { arch length }\end{array}$ & 86 & 0.22 & $2.07^{*}$ & 86 & 0.25 & $2.37^{*}$ & 86 & 0.23 & $2.17^{*}$ & 86 & 0.21 & 1.97 & 86 & 0.19 & 1.77 \\
$\begin{array}{l}\text { Lower dental } \\
\text { arch breadth }\end{array}$ & 86 & 0.15 & 1.39 & 86 & 0.40 & $4.00^{*}$ & 86 & 0.40 & $4.00^{*}$ & 86 & 0.41 & $4.12^{*}$ & 86 & 0.28 & $2.67^{*}$
\end{tabular}

*: Signifficant at the $5 \%$ level confidence

Bigonial breadth and upper dental arch breadth: There is a significant positive correlation in terms of the males, the females and the total of males and females.

Bigonial breadth and upper dental arch breadth: There is a significant positive correlation in terms of the males, the females and the total of males and females.

3. The correlation between heights.

Morphological face height and palatal vault height: There is a significant positive correlation in terms of the males and the total of males and females.

4. The correlation between lengths and breadths.

Head length and upper dental arch breadth: There is a positive correlation in terms of the total of males and females.

Head length and lower dental arch breadth. There is no significant correlation in terms of the males, the females and the total of males and females.

Head breadth and upper dental arch length : There is a positive correlation in terms of the total of males and females.

Head breadth and lower dental arch length : There is a positive correlation in terms of the total of males and females.

Bizygomatic breadth and lower dental arch length : There is no significant correlation in terms of the males, the females and the total of males and females.

Bizygomatic breadth and lower dental arch length: There is a positive correlation in terms of the total of males and females.

Bigonial breadth and upper dental arch length: There is a positive correlation in terms of the total of males and females.

Bigonial breadth and lower dental arch length: There is no significant correlation 
in terms of the males, the females and the total of males and females.

5. The correlation between lengths and heights.

Head length and palatal vault height: There is a positive correlation in terms of the total of males and females.

Morphological face height and upper dental arch length: There is a positive correlation in terms of the females and the total of males and females.

Morphological face height and lower dental arch length : There is no significant correlation in terms of the males, the females and the total of males and females.

6. The correlation between breadths and heights.

Head breadth, bizygomatic breadth, bigonial breadth and palatal vault height : There is no significant correlation in terms of the males, the females and the total of males and females.

Morphological face height and upper dental arch breadth : There is positive correlation in terms of the females and the total of males and females.

Morphological face height and lower dental arch breadth: There is a positive correlation in terms of the total of males and females.

\section{Summary and Discussion}

The infection of children with CRS have been reported by the following reporters; Aver, et al. (1965) ${ }^{2}$, Cooper, et al. (1969) ${ }^{3}$, Desmond, et al. (1963) ${ }^{4}$, Hirayama (1973) ${ }^{5}$, Horstmann, et al. $(1965)^{6}$, Menser, et al. (1969) ${ }^{7}$, Rudolph, et al. (1965) ${ }^{8}$, Sakugawa $(1976)^{9}$, Schiff, et al. (1969) ${ }^{10}$, Sever, et al. (1969) ${ }^{11}$, etc..

Although microcephalia and micrognathia are considered to be the defects of CRS, there is little report on microcephalia and micrognathia. The authors had conducted somatological measurement of the head and face of children with CRS previously with the following conclusions: compared to the control group, the children with CRS showed significantly smaller measurements in all items, except for the female bizygomatic breadth, and especially in the bigonial breadth, and they have a trend toward a short head and face. In the present paper, the correlations between the head and face, and the dental arch measurements have been reported and the summary and discussion are as follows.

I. Dental arch measurements

There have been no reports on the dental arch measurements of the children with CRS. According to the authors' results on upper dental arch length, the average for the CRS male is $37.09 \mathrm{~mm}$ and $35.85 \mathrm{~mm}$ for the female. The average for the control male is $37.72 \mathrm{~mm}$, and $36.70 \mathrm{~mm}$ for the female. The CRS group showed smaller measurements than the control group in terms of the males and the females, but it is insignificant.

As for the lower dental arch length, the average for the CRS male is $33.71 \mathrm{~mm}$, and 
$31.68 \mathrm{~mm}$ for the female. The average for the control male is $33.98 \mathrm{~mm}$, and $32.18 \mathrm{~mm}$ for the female. The children with CRS showed smaller measurements than the control, but it is insignificant.

As for the upper dental arch breadth, the average for the CRS male is $47.87 \mathrm{~mm}$, and $45.98 \mathrm{~mm}$ for the female. The average for the control male is $49.52 \mathrm{~m}$, and $47.42 \mathrm{~mm}$ for the female. The children with CRS showed smaller measurements than the control in terms of the males and the females, and it is significant.

As for the lower dental arch breadth, the average for the CRS male is $42.64 \mathrm{~mm}$, and $40.62 \mathrm{~mm}$ for the female. The average for control male is $44.61 \mathrm{~mm}$, and $42.39 \mathrm{~mm}$ for the female. The children with CRS showed smaller measurements than the control in terms of the male and female, and it is significant.

This result corresponds to the authors' previous report that the children with CRS showed significantly smaller bigonial breadth. Mori et al (1965) ${ }^{12}$ stated in his textbook that the development of the mandible is behind of the maxilla, i.e., at two to three months in utero, mandible is much smaller than maxilla, presenting micrognathia, but the mandible develops rapidly hereafter and balances with the maxilla. It is very interesting to know that the pregnant mothers were infected by rubella during the first trimester.

\section{The correlation}

Although the correlation between the head and face, and the dental arch has been reported by Sakai (male) (1955) ${ }^{13}$, Hamada (male and female) (1965) ${ }^{14}$, Minami (male, female and total of male and female) (1976) ${ }^{15}$, Kato (male, female and total of male and female) (1977) ${ }^{16}$, etc., of which materials are all healthy adults, it seems difficult to compare them with the authors' results. However, referring to the above, we have discussed the results as follows.

A. The correlation between lengths.

As for the correlation between lengths, according to the authors' results there is a significant positive correlation between head length and lower dental arch length in terms of the females and the total of males and females. According to the results of Sakai (1955) ${ }^{13}$, Hamada (1965) ${ }^{14}$, Minami (1976) ${ }^{15}$ and Kato (1977) ${ }^{16}$, there is no significant correlation between head length and upper and lower dental arch lengths.

B. The correlation between breadths.

As for the correlation between breadths, according to the authors' results there is a significant positive correlation in the males, between bizygomatic breadth and upper dental arch breadth, and between bigonial breadth and upper and lower dental arch breadths. According to Hamada (1965) ${ }^{14}$, Sakai (1955) ${ }^{13}$ and Minami (1976) ${ }^{15}$, there is no significant correlation between head breadth, and upper and lower dental arch breadths, being significant positive correlation between head breadth and upper dental arch breadth by Kato (1977) ${ }^{16}$.

Between bizygomatic breadth and upper dental arch breadth, Hamada (1965) ${ }^{14}$ and 
Kato (1977) ${ }^{16}$ stated that there is a significant positive correlation, and that corresponds to the authors' results.

Between bizygomatic breadth and lower dental arch breadth, Sakai (1955) ${ }^{13}$ and Kato (1977) ${ }^{16}$ stated that there is a significant positive correlation. Between bigonial breadth and lower dental arch length, Kato (1977) ${ }^{16}$ reported the significant positive correlation, which corresponds to the authors' results.

Between bigonial breadth and lower dental arch breadth, Sakai (1955) ${ }^{13}$ and Kato (1977) ${ }^{16}$ reported a significant positive correlation, and the authors' corresponding results showed a more positive correlation.

As for the females, Minami (1976) ${ }^{15}$ reported the significant positive correlation between bigonial breadth and upper and lower dental arch breadth. Kato (1977) ${ }^{16}$ reported a positive correlation only between bizygomatic breadth and upper dental arch breadth.

However, the authors' results showed a significant positive correlation between all head and face breadth, and upper and lower dental arch breadth. As for the total of males and females, the authors' results showed a significant positive correlation between all head and face breadth, and upper and lower dental arch breadth, as well.

C. The correlation between heights.

As for the correlation between heights, the authors' results showed a significant positive correlation between morphological face height and palatal vault height in terms of the males and the total of males and females. This corresponds to the results found by Sakai (male) (1955) ${ }^{13}$, Minami (female) (1976) ${ }^{15}$, Minami (total) (1976) ${ }^{15}$ and Kato (total) (1977) ${ }^{16}$.

D. The correlation between lengths and breadths.

As for the correlation between lengths and breadths, the authers' results showed a significant positive correlation in terms of the total of males and females, between head length and upper dental arch breadth, head breadth and upper and lower dental arch length, bizygomatic breadth and lower dental arch length, bigonial breadth and upper dental arch length.

Minami (1976) ${ }^{15}$ reported a significant positive correlation in the females, between head breadth and bizygomatic breadth and upper dental arch length, and between bigonial breadth and upper and lower dental arch length, in the total of males and females, between head breadth and bizygomatic breadth and upper and lower dental arch length, between bigonial breadth and lower dental arch length.

On the other hand, Kato (1977) ${ }^{16}$ reported a significant correlation in the males, between head breath and bizygomatic breadth and lower dental arch length, in the females, between head length and upper dental arch breadth, between bizygomatic breadth and upper and lower dental arch lengths, in the total of males and females, between head length and upper dental arch length, between head breadth and bizygomatic breadth and upper and lower dental arch length. 
Minami (1976) ${ }^{15}$ reported a significant negative correlation, in the male, between head length and lower dental arch breadth.

E. The correlation between lengths and heights.

As for the correlation between lengths and heights, the authors' results showed a significant positive correlation in the females and the total of males and females, between morphological face height and upper dental arch length in the total of males and females, between head length and palatal vault height.

Kato (1977) ${ }^{16}$ reported a significant positive correlation in the total of males and females, between head length and palatal vault height, corresponding to the authors' results.

F. The correlation between breadths and heights.

As for the correlation between breadths and heights, the authors' results showed a significant positive correlation in the females and the total of males and females, between morphological face height and upper dental arch breadth, in the total of males and females, between morphological face height and lower dental arch breadth.

Kato (1977) ${ }^{16}$ reported a significant positive correlation in the males, between head breadth and palatal vault height, between morphological face height and upper and lower dental arch breadths, in the females, between morphological face height and upper dental arch breadth, in the total of males and females, between head breadth and palatal vault height, between morphological face height and upper and lower dental arch breadths.

Minami (1976) ${ }^{15}$ reported a significant positive correlation in the females, between morphological face height and upper dental arch breadth, in the total of males and females, between morphological face height and upper dental arch breadth, between bizygomatic breadth and bigonial breadth and palatal vault height.

As described in the above, the correlation for the children with CRS between the head and the face, and the dental arch showed more positive results in the maxilla than in the mandible, and more positive results in the head than in the face.

\section{Conclusions}

In August, 1977, Okinawa prefecture, the authors conducted the somatological measurement of head and face, and the impression taking of the upper and lower dental arches of the children with CRS; 53 males, 49 females and 102 total.

After examining the correlations between the measured values of the head and face, and the dental arch, we have reached the following conclusions:

I. Measured values of the dental arch.

1. Upper dental arch length.

Average for the male is $37.09 \mathrm{~mm}$, and $35.85 \mathrm{~mm}$ for the female.

2. Upper dental arch breadth. 
Average for the male is $47.87 \mathrm{~mm}$, and $45.98 \mathrm{~mm}$ for the female

3. Palatal vault height.

Average for the male is $13.83 \mathrm{~mm}$, and $13.87 \mathrm{~mm}$ for the female.

4. Lower dental arch length.

Average for the male is $33.71 \mathrm{~mm}$, and $31.68 \mathrm{~mm}$ for the female.

5. Lower dental arch breadth.

Average for the male is $42.64 \mathrm{~mm}$, and $40.62 \mathrm{~mm}$ for the female.

6. The dental arch length and breadth of the CRS group is smaller than those of the control.

II. Correlation.

1. In terms of lengths, there is a significant positive correlation in the females and the total of males and females, between head length and lower dental arch length.

2. In terms of breadths, there is a significant positive correlation in the females and the total of males and females, between head breadth and bizygomatic breadth, and between bigonial breadth and upper and lower dental arch breadth, in the male, between bizygomatic breadth and upper dental arch breadth, between bigonial breadth and upper and lower dental arch breadth.

3. In terms of heights, there is a significant positive correlation in the males and the total of males and females, between morphological face height and palatal vault height.

4. In terms of lengths and the breadths, there is a positive correlation in the total of males and females, between head length and upper dental arch breadth, between head breadth and upper and lower dental arch lengths, between bigonial breadth and upper dental arch length.

5. In terms of lengths and heights, there is a positive correlation in the females, between morphological face height and upper dental arch length, in the total of males and females, between morphological face height and upper dental arch length.

6. In terms of breadths and heights, there is a positive correlation in the females, between morphological face height and upper dental arch breadth, in the total of males and females, between morphological face height and upper and lower dental arch breadths.

\section{References}

1. Martin, R. and Saller, K. : Lehrbuch der anthropologie. Bd. 1, 3 Auflage, Gustav Fischer Verlag, Stuttgart, 1956, 379-380.

2. Aver, G.B., Monif, G.G.R., et al.: Rubella syndrome after inapparent maternal illness, Am. J. Dis. Child. 110:444-446, 1965.

3. Cooper, L.Z., Ziring, P.R., et al.: Rubella-Clinical manifestations and management, Am. J. Dis. Child. $118: 18-29,1969$. 
4. Desmond, M. M., Montgomery, J. R., et al. : Congenital rubella encephalitis. Effect on growth and early development, Am. J. Dis. Child. $118: 30-31,1963$.

5. Hirayama, M. : Congenital rubella syndrome Okinawa. - Developmental status of the cases-, Advances in Neurological Sciences $17: 15-21,1973$.

6. Horstmann, D. M., Banatvala, J.E., et al.: Maternal rubella and the rubella syndrome in infants. Epidemiologic, clinical, and virologic observations, Am. J. Dis . Child. 110:408-415, 1965.

7. Menser, M. A., Dorman, D.C., et al. : Congenital rubella. Long-term follow-up study, Am. J. Dis. Child. 118: 32-34 1969.

8. Rudolph, A.J., Singleton, E. B., et al. : Osseous manifestation of the congenital rubella syndrome, Am. J. Dis. Child. 110:428-433, 1965.

9. Sakugawa, H. : An investigation of the developmental neurology in congenital rubella syndrome, Psychiatria et Neurologia Japonica $78: 587-609,1976$.

10. Schiff, G. M., Sutherland, J. M., et al. : Studies on congenital rubella, Am. J. Dis. Child. $110: 441-443,1965$.

11. Sever, J. L., Hardy. J. B., et al. : Rubella in the collaborative perinatal reseach study. II . Clinical and laboratory findings in children through 3 years of age, Am. J. Dis. Child. $118: 123-132,1969$.

12. Mori, M., and Saegusa, H. : Oral Histology, Nagasue Shoten, Kyoto, 1965, 196.

13. Sakai, T.: On the correlations of form and size between head and face, and dental arch and palate, Shinshu Med. J. 4:45-48, 1955.

14. Hamada, S. : A study on the correlations between various measurements on human dental arch and shose on the body, Nihon Univ. dent. J. 39:455-462, 1965.

15. Minami, Y. : Somatological measurements of head and face on the inhabitants in miiraku, a chain of Goto islands, Kyushu, Japan, and correlation between they and measurements of dental arches, J. Kyushu. Dent. Soc. 30:152-169, 1976.

16. Kato, Y.: Somatological measurements of head and face of the inhabitants of Katsumoto, Iki island, Kyushu, Japan and correlation between those values and measurements of dental arches, J. Kyushu Dent. Soc. $30: 976-988,1977$. 


\title{
先天性風疹症候群児の頭顔部と雪列弓の相関について
}

\author{
九州菌科大学解剖学教室（主任：山田 博） \\ 村上守良, 六及丒篤, 伊東励 \\ 九州歯科大学口腔衛生学教室（主任：佐伯栄一) \\ 伊波富夫, 祐出彰, 佐伯栄一
}

1964年から1965年にかけて沖縄で大流行した風疮は， 妊娠中であった母親に感染し, 䍜患した母親からは種々 の障害をもった子が出生した，その後風疹の人体への影 響について種々の分野から多数の研究報告がなされてき た.その臨床像の一つに小頭症が挙げられており，また micrognathia などの 異常が報告されている．頭顔部 領域の研究報告は少なく，中でも頭顔部および函列弓の 形態についての報告はまったくみられない，著者らは発 症後12年を経過した昭和 52 年 8 月, 沖縄の先天性風疹症 候群児102名（男53名, 女49名）について頭顔部の生体
計測ならびに歯列の印象採得を行い，乙れらの間におけ る相関関係について検討した結果，次のでとき結論をえ た。

1. 先天性風牀症候群児の雪列马は正常児に比し, 上 下の雪列马長および幅は小さく，特に幅において著し い.

2. 先天性風疮症候群児の 頭顔部之柬列弓との 相 関 は, 脳頭蓋より顔面頭蓋に強く, 男より女に多くの項目 で正の相関関係がみられた。 